\title{
Heterycki separatyzm: dziesięć tez o kłirowym archiwum
}

\section{Stanimir Panayotov}

Central European University

\begin{abstract}
Poniższy tekst jest poprawiona wersja referatu wygłoszonego podczas konferencji In/visible: The Sexual and Political Regimes of the Archive w ramach panelu "The Queer Location of Culture: Nationalism, History, Sexuality", Skopje, National Gallery of Macedonia - Chifte Hamam,

25 lutego $2012 r$.
\end{abstract}

Stowa kluczowe: queer, heterycki separatyzm, archiwum

Teza 1: Cała kultura jest archiwum heteroseksualności i tożsamości, bowiem jedno implikuje drugie. Bitwa o pamięć jest bitwą o uznanie tożsamości wykluczającej, a nie wykluczonej. Istotą kultury jest polityczne samookreślenie jednej tożsamości - heteryckiej - kosztem zorganizowanej autodestrukcji wszystkich pozostałych. Odmieńcy istnieją poprzez popęd śmierci, podczas gdy instytucja archiwum istnieje, by go łagodzić.

Teza 2: Ponieważ współczesne społeczeństwo jest rozbite na pojedyncze, kulturowo definiowane tożsamości przez politykę tożsamościowego totalitaryzmu, całe społeczeństwo i jego instytucje - w tym także muzeum - są obozami erotycznie ubarwionego separatyzmu. Sposoby formalizacji pamięci są separatystycznymi strategiami heteryckiego przetrwania. Kłirowe archiwum jest ogromną, ciemną, tanatologiczną i eschatologiczną otchłanią pragnień, której formalizacja nie prowadzi do zreformowania fałszywego uniwersalizmu heteryckiego separatyzmu. Kłirowe wkluczanie jest gettoizacją kwestii różnicy w obrębie biopolitycznych obozów heteryzmu. Należy albo zmienić formy instytucji, albo w ogóle porzucić upamiętnianie.

Teza 3: Forma instytucji, która jest biopolitycznym miejscem wykluczenia, jest również polem bitwy o tożsamość. Jednak bitwa ta toczona jest na gruncie heteryckiego imaginarium i heteryckiego ciała. Kwestia pamięci nie jest kwestią wykluczenia, ale raczej tego, czy my, kłirowi odmieńcy, chcemy zmumifikować się w tożsamość, czyli formę ponadhistorycznego przetrwalnictwa zaprojektowaną dla mitomańskich heteryków.

Teza 4: Instytucja jest reprodukowaniem (heteryckiej) tożsamości. W tym sensie jest odgrodzeniem się, które komunikuje: „nie ty”. Na tyle, na ile jest to forma heterycka oraz na ile tożsamość jest sformalizowaniem heteryckości, instytucja jest socjokulturowym gettem heteroseksualności. Odczuwane przez odmieńców pragnienie archiwizowania się i przybrania tożsamości jest odwróconą formą 
heteryckiego sadyzmu. Wtargnięcie do heteryckiego getta nie ma dowodzić ludzkiej uniwersalności, tylko umożliwić dołączenie do łupów partykularyzmu i fałszywej świadomości.

Teza 5: Włączenie odmieńców w instytucjonalne formy nie jest krokiem w kierunku uniwersalności: jest poddaniem się imperatywowi uznania. Tak jak kwestia jednopłciowych małżeństw dotyczy jedynie prawa do małżeństwa, nie zaś obowiązku, tak jak chcemy stać się częścią skorodowanej już historii uniwersalności - małżeństwa, podpartego swą przemocową przeszłością, tak samo objęcie instytucjonalnym patronatem kłirowego archiwum jest jedynie pragnieniem zdywersyfikowania tej samej formy instytucjonalnej opresji, która funkcjonuje już od dawna, czyli getta wykluczeń.

Teza 6: Tworzenie (i kłirowanie formy) instytucji jest aktem nihilizmu, samonienawiści i kolejną zmodyfikowaną formą społecznie narzuconej autodestrukcji. Dlatego archiwum kłirowe powinni tworzyć heteryccy separatyści - czyli społeczeństwo zdominowane przez tożsamościowo-faszystowską formę instytucji; tylko dzięki pozostawieniu tego zadania heterykom możemy nadal cieszyć się naszymi anomicznymi pragnieniami, bowiem każde pragnienie jest anomiczne. Jeśli heteryccy separatyści nie są w stanie stawić czoła swej partykularności i ogłosić jej w ramach represyjnego paradygmatu uznania (który jest jedynym dostępnym im sposobem performatywnego doświadczania dokonywanych wykluczeń), to nie możemy zmienić biegu historii i pamięci.

Teza 7: Kłirowa pamięć i archiwum są immanentne; ucieleśniają immanentną materialność (lub też: komunalno-telepatyczną transmisję historii miłosnych). Odwrotnie niż heterycki separatyzm $w$ formie instytucji ze swoim tożsamościowym faszyzmem, kłirowe archiwum jest praktyką codziennego życia. Wykluczone artefakty różnicy seksualnej są wystawione na pokaz w zbiorowych pamięciach naszych splątanych ciał, posiadających swoje historie ruchania, miłości, czułości. Nasze wspomnienia są naszymi muzeami.

Teza 8: Formalizacja upamiętniania i pamięci różnicy seksualnej nie może być nienormatywna. Tym, co łączy wszystkie takie próby, zarówno kłirowe, jak i heteryckie, jest porażka wspólnej uniwersalności i wspólnego projektu społecznego. Wszystko, na co możemy liczyć, to przekształcenie istniejącej inherentnie między nami antyspołeczności w politykę skutecznego nieporozumienia.

Teza 9: Jedynym kłirowym archiwum, jakie możemy stworzyć, nie zaprzedając się fałszywemu uniwersalizmowi ani heteryckiemu separatyzmowi, jest przekroczenie paradygmatu miłości i paradygmatu uznania. Jedynym sposobem zmiany formalizacji pamięci i przeciwdziałania zapominaniu jest porzucenie paradygmatu uznania. Zostawmy pamiętanie kłirowo-heteryckim biurokratom.

Teza 10: Tworzenie kłirowego archiwum jedynie obnaża fałszywą świadomość: pseudouniwersalnej heteroseksualności i zasymilowanej odmieńczości. Jedyna znacząca zmiana, która jest możliwa do osiągnięcia, to (1) obnażenie zarówno instytucji, jak i tożsamościowego faszyzmu jako składników fałszywej świadomości, a co za tym idzie, (2) włączenie się w proces przepisywania 
separatyzmu heteryckiego na kolektywny. W innym wypadku należy zrezygnować ze wszelkich sposobów upamiętniania.

Ttumaczenie: InterAlia Tekst oryginalny zostat opublikowany w czasopiśmie InterAlia nr 11a/2016.

\section{Straight Separatism: Ten Theses on the Queer Archive}

This text is a revised version of a paper presented at the conference In/visible: The Sexual and Political Regimes of the Archive, in a panel titled "The Queer Location of Culture: Nationalism, History, Sexuality" (Skopje, National Gallery of Macedonia - Chifte Hamam, 25 February 2012).

Keywords: queer, straight separatism, archive 